\title{
The Influence of Information Technologies on Financial Market
}

\author{
Ekaterina Y. Kalmykova \\ Department of Management \\ National Research Tomsk Polytechnic University \\ Tomsk, Russia \\ kalmykova@tpu.ru
}

\author{
Anna V. Ryabova \\ Department of Management \\ National Research Tomsk Polytechnic University \\ Tomsk, Russia \\ avr5@tpu.ru
}

\begin{abstract}
Article represents a new tendency - FinTech, a new market which is caused by fast development of technologies and which is today very attractive for investors. The authors introduce a great number of its different concepts: P2P-crediting, E-wallets, Bitcoins, mPOS-acquiring, T-commerce, mobile banks, etc. They are clearly described them as well-known tools not only for economists but also for majority of population. Many examples of their using in ordinary life are also presented. In spite of the fact that these tools make life easier they are, however, changing financial, monetary and credit systems of many countries. The influence of FinTech on these players of financial market is analyzed to improve their role in modern economy. Some problems and examples of FinTech regulation are also shown. Making conclusion the authors stress the influence of FinTech on the financial market and its importance for economy.
\end{abstract}

Keywords-FinTech, financial technologies, startups, financial market, financial regulation, innovations

\section{INTRODUCTION}

The active development of information technologies are spreading through all spheres of our life. Financial market is not an exception - there is a new perspective area of focus which is called "FinTech" of financial technologies. Nowadays, it is the market of financial technologies which is known to be one of the fastest growing markets.

Equiering, P2P, bitcoins, online banking, e-wallets and other specific terms have become so clear and ordinary that we start using them in our everyday life. As a result of their fast growth financial, credit and monetary systems are extensively changing in many countries. Cash is going to be replaced by e-wallets and online-payments, bank credits - by loans that you can take out from other people through the Internet. All these innovations make banks to create new instruments of lending because it is going to be the only way for keeping their clients.

\section{MAIN ASPECTS OF FINTECH}

\section{A. FinTech definition}

Today there is no definition of FinTech in Russian in spite of the fact that this term has already been used by many people for several years.

According to foreign sources FinTech or financial technologies mean:

- An economic sector which consists of companies that use technologies to provide financial services more efficiently. The companies of this industry on the whole are start-ups which were set up to make a breakthrough in already existing financial systems and organizations that do not have software products.

- A segment of technology start-ups activity which are disrupting sectors such as mobile payments, money transfers, loans, fundraising and even asset management [4].

- A line of business based on using software to provide financial services [3].

The term "FinTech" was coin by Silicon Valley. It is a place where lots of IT projects has been designed and which later answered for a sort of "accelerator" to modern financial technologies. Today it is London that is known as the capital of FinTech because of the number of fintech innovations and its investment flow. Great Britain has four main factors determined to encourage the development of FinTech: intensive infrastructure, literate legal framework, verifiable tax system and investment support in the country.

FinTech was engendered in the USA and Europe earlier than in Russia. It came to domestic market only in 2008 when cellular operators took part in the development of mobile payments. Today Russian market of FinTech is still in arrears of foreign markets but it has an active growth.

\section{B. FinTech types}

By now this market has a great number of different concepts: P2P-crediting, E-wallets, Bitcoins, mPOS-acquiring, T-commerce, mobile banks, etc. For the first time they may 
seem to be unknown but if we get some more information about them we will understand them at once.

We will start with $\mathrm{P} 2 \mathrm{P}$ lending, very widespread technology now. This abbreviation is expanded like "peer-topeer" or "person-to-person" lending, i.e. lending from one person to another. This term means there are only two participants (in most cases they are natural persons) in the process of loan granting without any intermediary agents such as banks and credit institutions. There are special web sites where a user can be borrower as well as lender. The biggest part of providing credits within such services belongs to not assured private loans. However, sometimes the involvement of companies (legal bodies) is also possible. In case of P2P lending risk is higher because it is impossible to check the real credit history of borrower in most cases and to make his loan scoring. Correspondingly, interest rates for to these credits will be relatively overstated. Thus creditors prefer to lend many small loans to many loaners to decrease their non repayment risks.

Zopa (Zone of Possible Agreement) which was founded in 2005 in UK became the first P2P lending service in the Internet. In a year USA had also some P2P companies, e.g. Prosper and Lending Club. In Russia these technologies appeared only in 2010 but they started functioning only two years later. At the present there is credit exchange house which is based on the Webmoney service and another one is Vdolg.ru, a project of Banki.ru.

Apart from "lending" technologies there is another interesting gap in the market fo Russia - personal data. For example, "Sberbank" or other banks have enough information about their clients - they know the wage of a client, how much money he draws, where he spends it and on what. The only ones who get more data than baks are cellular operators. They know how much time is spent on calls, who is a talker, how much time a client is abroad, what additional services he uses. All this information is a part of supplementary financial services and, moreover, is a part of analytics of these services' working.

At the moment this issue is very popular on the overseas market. All great mobile companies such as AT\&T, Vodafone, T-Mobile have already been processing data. In Russia the sphere is only in prospect. The combining of FinTech market and processing data will bring about the opportunity of further economy development in general.

Another very popular financial technology is E-wallet or electronic wallet which lets pay for any goods and services through the Internet. Especially for developing this concept there is an official law which runs up the maximum size of possible sum of money in your E-wallet - from 100,000 rubles to 400,000 rubles. So, now it is multiplied by four. Russian market of E-wallets have 6 players who get the more active positions - five of them are domestic service (Webmonety Transfer, Yandex.Money, QIWI, RBK Money, Dengi@mail.ru), the last one is foreign (International moneytransfer system PayPal).

One of the most popular electronic systems in CIS (Commonwealth of Independent States) is Webmoney
Transfer oriented on money exchanging and conducting transactions of online currency. It offers a lot of functions, opportunities and operations on finance instantly produced.

The second famous payment system in CIS is Yandex.Money which provides safety exchange and transfer of online currency to other users keeping all necessary data about your operations.

The next Russian service on this market is QIWI functioning today in more than 20 countries all over the world. It specializes on instantaneous payments of any services including various utility bills, banking credits, etc. However, in contradistinction to other payment systems, this one has a feature - special self-service payment terminals. So you can pay for your bills not only through the Internet or by your mobile phone.

RBK Money or RUpay is a single payment platform working in real time mode. With this service you can make fast and safety any operation on your online money. The main purpose of this technology is paying for bills and purchases in the Internet, doing cashout.

The last domestic company among above mentioned players is Dengi@mail.ru which confines itself to its interface. Payments are possible for making with any personnel computer or device because the only thing which you need for your identification is your e-mail.

International money-transfer system PayPal is a serious foreign competitor for Russian companies. It is one of the most popular services of the world; it was based in 1998 and nowadays it is used by more than $100 \mathrm{~m}$ users. Within this system users register simply their private account; major customers can set up a business account. In Russia PayPal is available only for paying for shopping. Electronic currency cannot be taken out or be admitted from other users.

Apart from E-wallets allowing controlling the purse strings online, there was created completely numerical P2P currency - Bitcoin. It is intended to be a substitute for cash when you do shopping in the Internet. Unlike most of types of e-money which are kept on bank deposits and transferred with the aid of different payment systems, bitcoins are used outright between clients without any intermediary agents. That is why bitcoins become a real direct rival for native currencies.

Today paying by credit cards for shopping is an everyday occurrence. Nevertheless, shops have to set up special POSterminals to make transactions with credit cards. At small shops, stands, kiosks there is a difficulty to provide such terminals, that is why there is a necessity of cash all the time to buy any products. To solve this problem there is a new technology - Mobile Point of Sale, or for shot mPOS terminal.

The terminal is represented like computer device which you have to connect to your mobile phone or tablet computer and it allows doing cashless transfers by your credit card. It is especially valuable for small and portable business, sole traders. For example, delivery agents of any products or documents can use this technology device to get refund for delivery on site. It is very convenient for company as well as for clients because they do not need to withdraw money before 
making the order. By dint of mPOS terminals many firms are able to increase their profitability, for that reason its demand is very high on the market. By the way, investment analysts also mark the active growth of this devices. For example, according to Smart Insights research the number of mPOS terminals will exceed the number of POS terminals and will have achieved $52 \mathrm{~m}$ pieces by 2018 [10].

The leader of this field in Russia is LifePay. The project has appeared more than 6 thousand users for a half year. During 2013 the total sum of money of all transactions which were made by the mPOS readers was more than $\$ 1 \mathrm{~m}$. The most successful mPOS companies on the world market are Square, SumUp, iZettle, mPowa.

Regarding using of smart phones and tablet computers to do any financial transactions, it stands to mention another concept - T-commerce - which is directly concerned with modern gadgets. It stands for tablet-commerce. This term was coined by specialists from Silicon Valley due to the fact of beginning of "mobile" era in economy. Steady growth on mobiles and tablets market is registered all over the world, so it is fertile ground for t-commerce evolution.

Furthermore, mobile banking is also developing. The term means using of special bank application to do some functions wherever you are. For example, Sberbank has created an application "Sberbank online" that helps users to transfer money from their bank cards to others, to clear different bills, to open an account, to look through transactions' list and so on. In the meantime, the application is free and there is no additional service fee when you make a transaction. In addition to Sberbank there are also Alfa-bank, Gazprombank, VTB 24 and many other banks in Russia that have such application.

There is also online-banking. It similar to mobile banking but it is not the same. Online banking has the same functions like mobile banking but it is considered as a web bank. Thus, such banks have no branches, no departments, it means that you cannot visit it. The banks work with their client only through the Internet or using special applications that is why this system helps to reduce costs of a bank.

\section{FinTech classification}

Due to fast FinTech market growth there is a need of its classification. In general there are seven different types of organizations [1]. They are the following:

1. Lending. Private landing companies, P2P-lending, lending platforms using machines learning technologies and algorithms to assess creditworthiness.

2. Payments or Billing Tech. Payments processing, bill preparing.

3. Personal Finance or Asset Management that help in managing personals bills, accounts, credits, investments.

4. Money Transfer or Remittance. P2P-platforms to transfer money between clients across countries.

5. Digital currency. Software in the digital currency sphere.
6. Institutional tools providing tools to banks, hedge funds, mutual funds or other institutional investors.

7. Equity crowdfunding - platforms for providing monetary contribution for projects or companies.

There are also some other groups of companies:

- venture capital firms that make venture equity investments across the stage spectrum and geographies focusing on Fin Tech companies

- $\quad$ corporate investors, both corporations making direct investments and separately identifiable corporate venture units

- $\quad$ angel investors, individual angel investors who offer early-stage capital, advice and networks to startups in exchange for equity or convertible debt

- $\quad$ accelerators (incubators) that offer some combination of equity investment, mentorship and resources around company development

- $\quad$ FinTech acquirers, key public corporations that have acquired private FinTech companies in the last five years.

- $\quad$ notable exists key FinTech companies that have been acquired or went public in the last 5 years ranging from lending and money transfer firms to personal finance and bill paying tools.

\section{FINTECH REGULATION}

In spite of the fact that fintech market is fast spreading today and there are lots of new start-ups every month, there is still no legal regulation by the government.

Financial technologies develop so fast that it is difficult to manage to all its innovative features in case of legal control. However, it is a problem not only for government but for startupers and customers as well. So fintech regulation is becoming a global issue.

Today many countries have special institutes to control firms from financial market. For example, in UK there is Financial Conduct Authority, an independent non-government body. The FCA has the power to regulate firms in the financial sector and its responsibilities are applying standards and requirements for financial products, regulating marketing and financial products' conduct, investigating firms and applying bans where deemed appropriate. It is regulated such players of the market as banks, credit companies, mutual societies and financial advisors. Thereby it is free to control some of fintech start-ups.

The UK regulates certain activities carried on in relation to a range of payment, investment and lending propositions which means, as a general rule, a FinTech business needs to consider at an early stage whether it requires regulatory approval to conduct business in the UK. A surprising range of business models need regulatory approval to operate in the UK - even when they are not based in the UK.

The FCA's application process, if managed well, need not be overly complicated or intrusive. The typical authorization timeframe with appropriate resources in place can comprise a 
six week pre-submission preparation period, followed by a statutory post-submission period (of up to six months) for the FCA to consider the application [2].

Regarding USA, there are other instruments of regulation. The U.S. Securities and Exchange Commission (SEC), for instance, is an agency of the U.S. federal government which is the main control authorities within securities market in the United States. It holds primary responsibility for enforcing the federal securities laws, proposing securities rules, regulating the securities industry and so on.

One of acts enforced by SEC is the Securities Act of 1933, a federal act according to which investors are able to be informed about investments and which let establish laws against misrepresentation and fraudulent activities in the securities markets. For companies working with investments the Act should be very important because in case of its breach a company would face not only civil but also criminal charges. In that way, lending companies, such as "Prosper" or "Lending Club", had to register securities with the SEC because in 2008 SEC decided their activities to be in violation of the Securities Act of 1993 - the peer-to-peer loans the companies provided to earn a profit in the form of interest were at a rate higher than that available from depository accounts at financial institutions [5].

Last year SEC announced a new set of rules implementing Title IV of the JOBS Act or the Jumpstart Our Business Startups Act which intend to encourage funding of U.S. small businesses by easing various securities regulations. These new rulings will be done initially through what are called Regulation $\mathrm{A}+$ investment offerings. According to this now more people can take part in early-stage investment and companies are able to increase their capital with less regulatory burdens. For FinTech market these rules are really important and very helpful when developing new platforms. Thus, fintech startups will be responsible for complying with the regulations but with no case law yet to guide them while investors will still be limited in how much they can invest and with whom [8].

Apart from SEC, there is also Financial Industry Regulatory Authority, Inc. (FINRA) which regulates member brokerage firms and exchange markets. Contrary to SEC FINRA is non-governmental organization and, moreover, it is the successor to the National Association of Securities Dealers (NASD) and the member regulation, enforcement and arbitration operations of the New York Stock Exchange.

When considering loaning money to individuals whether as a creditor or within the investment process, lending laws come into the picture. Usually these laws are set at the state level, and they restrict thing including who you can lend to, how much you can lend and the interest rates charged to borrowers. Each fintech startup in USA should take care to comply with lending laws that go hand in hand with securities regulations [6].

Unfortunately, Russia has still no legal regulation of FinTech. It connects to its later coming to Russian market. Nevertheless, Central Bank is an active participant of FinTech development in Russia. The most attractive and challenging the same time fintech project for Central Bank is Bitcoin, of course. Firstly, it wanted to abolish the digital currency and make using Bitcoin punishable by law. Then the Bank decided to explore the possibilities and boundaries of Bitcoin technology.

Some time ago the Central Bank announced that it wanted to be a part of FinTech evaluation in Russia. It has already set up a taskforce for the sole purpose of exploring what can be done in the short and long run. The taskforce will hold regular meetings to discuss the technologies they discovered and how they can be useful to the Bank of Russia [7]. Today it is also creating a self-regulating board that allows industry players to collaborate on fintech efforts with others [9].

\section{CONCLUSION}

So it is possible to sum up that the modern FinTech tools have considerable impact on economies of different countries, in particular on banks and credit systems. On the one hand, they pose threat for banks and credit institutes as they actively drive them out on the market due to their modernity and utility. However, on the other hand, it is possible to tell that financial technologies increase quality of the services provided by banks and give an impetus to their productive development towards informatization.

There is no doubt that fintech regulation is not still ready for total control of new startups and theirs technologies. Despite this fact, there are a great number of upcoming trends now which will probably lead to a new economic business model in the end.

\section{ACKNOWLEDGMENT}

This research was supported by National Research Tomsk Polytechnic University.

\section{REFERENCES}

[1] CB Insight, "The Periodic Table of Fin Tech Press", 2015. URL: https://www.cbinsights.com/blog/fin-tech-periodic-table/

[2] C. Woolard, "UK FinTech: Regulating for innovation", 2016. URL https://www.fca.org.uk/news/uk-fintech-regulating-for-innovation

[3] Fintech Weekly, Fintech Definition. URL https://www.fintechweekly.com/fintech-definition

[4] J. Munch, "What is fintech and why does it matter to all entrepreneurs", 2015. URL: https://www.hottopics.ht/stories/finance /what-is-fintechand-why-it-matters/

[5] L. Downes, "Five legal threats for fintech's hottest start-ups", The Washington Post, 2015. URL: https://www.washingtonpost.com/news/innovations/wp/2015/08/27/fivelegal-threats-for-fintechs-hottest-start-ups/

[6] N. Athwal, "Fintech Startups Navigate Legal Gray Areas To Build Billion-Dollar Companies”, $2015 . \quad$ URL: http://techcrunch.com/2015/04/19 /fintech-startups-navigate-legal-grayareas-to-build-billion-dollar-companies/

[7] Priori Legal, "Securities Regulation for FinTech Startups". URL: https://www.priorilegal.com/securities/securities-regulation-for-fintechstartup

[8] OneStopBrokers, "Bank of RussiaSets up Teskforce to Explore Bitcoin and FinTech", 2016. URL: http://www.onestopbrokers.com/2016/02/29/ bank-russia-sets-taskforce-explore-bitcoin-fintech/ 
[9] R. Kennedy, "Bank of Russia Pushes for Fintech, Payment Week", 2016. URL: http://paymentweek.com/ 2016-3-3-bank-of-russia-pushesfor-fintech-9812/

[10] Smart Insights, "Mpos market dynamics will reduce traditional pos sales by 10 million units according to smart insights report", 2014. URL: http://www.smartinsights.net/Company/Our-news/mPOS-marketdynamics-will-reduce-traditional-POS-sales-by-10-million-unitsaccording-to-Smart-Insights-Report 